\title{
De invloed van organisatiekenmerken op werkdruk in organisaties
}

\author{
Noortje Wiezer, Peter Smulders en Ruud Nelemans*
}

\begin{abstract}
Aan de gevolgen van werkstress en werkdruk wordt vooral in de wetenschappelijke literatuur veel aandacht besteed. De oorzaken van werkdruk worden echter veel minder vaak onderzocht. In dit artikel bespreken we een aantal mogelijke oorzaken van werkdruk. Werkdruk wordt meestal bestudeerd vanuit het perspectief van werknemers. Voor dit onderzoek maken we gebruik van gegevens over werkdruk verzameld onder werkgevers in Nederland. De gegevens zijn verzameld in 2001, bij 3.199 bedrijven. Multivariate regressieanalyses laten zien dat 'een complexe en instabiele omgeving' een belangrijke voorspeller is van hoge werkdruk in bedrijven. Ook de mate waarin in bedrijven sprake is van procesvernieuwing blijkt een voorspeller te zijn van hoge werkdruk, net als de mate waarin sprake is van flexibilisering (en dan vooral kwantitatieve flexibilisering). De aanwezigheid van regelmogelijkheden blijkt samen te hangen met werkdruk. De belangrijkste factor blijkt echter de aard van het werk te zijn. Werkdruk stijgt naarmate er meer sprake is van lichamelijk zwaar werk.
\end{abstract}

Trefwoorden: werkdruk, oorzaken, risicosectoren

\section{Inleiding en probleemstelling}

Werken onder hoge tijdsdruk is een van de belangrijkste veroorzakers van werkstress en burnout (zie bijvoorbeeld French \& Caplan, 1970; French, Rogers \& Cobb, 1974; Kompier et al., 1996; Jones et al., 1998; Cox, Griffith \& Rial-González, 2000). Het percentage nieuwe WAO'ers met als (hoofd) diagnose 'psychische stoornissen' is in de periode 1996-2001 gestegen van 30 naar 36. Het aandeel werkgebonden aandoeningen bij psychische ziekten is relatief hoog $(44 \%)$, en dit betreft vooral overspannenheid en burnout (NCvB, 2001 en 2002). Werkdruk, als belangrijke veroorzaker van deze beroepsziekte, is nog steeds een belangrijk aandachtspunt van de overheid. Het ministerie van Sociale Zaken en Werkgelegenheid (SZW) probeert via Arboconvenanten bedrijven en instellingen te stimuleren werkdruk te verminderen. Voorts zijn werkdruk en preventieve acties ter voorkoming van werkdruk een van de zes prioriteiten van de arbeidsinspectie (zie jaarplan 2003: www. Arbeidsinspectie.nl).
Hoge werkdruk heeft niet alleen gevolgen als werkstress en burnout. Een hoge werkdruk leidt tot vermoeidheid en een grote vermoeidheid weer tot een grotere kans op ongevallen (zie bijvoorbeeld Goldenhar, Williams \& Swanson, 2003). Maar ook het feit dat medewerkers het onder tijdsdruk niet zo nauw nemen met de veiligheidsvoorschriften of het feit dat ze simpelweg geen tijd hebben om de voorschriften te volgen, kan de kans op ongevallen vergroten. Een te hoge werkdruk kan leiden tot fouten en een vermindering van kwaliteit en productiviteit, motivatie en tevredenheid van medewerkers en tot verloop.

De gevolgen van werkdruk voor de gezondheid van medewerkers komen, vooral in de wetenschappelijke literatuur, uitgebreid aan de orde. Veel minder aandacht wordt besteed aan de oorzaken van werkdruk (zie ook Smulders \& Houtman, 2004). In dit artikel willen we ons vooral daarop richten. De vraag die we hier willen beantwoorden is: wat zijn de oorzaken van werkdruk in organisaties?

* Dr. N.M. (Noortje) Wiezer, dr. P.G.W. (Peter) Smulders en drs. R.J.C. (Ruud) Nelemans zijn werkzaam bij TNO Kwaliteit van Leven I Arbeid. E-mail: n.wiezer@arbeid.tno.nl. 
In dit artikel wordt een onderscheid gemaakt tussen de begrippen werkdruk en werkstress. Met werkdruk bedoelen we een situatie waarin een medewerker veel werk in een korte tijd moet doen, zodat hij of zij onder hoge tijdsdruk moet werken. Werkdruk kan ontstaan in een situatie waarin sprake is van hoge taakeisen, maar waar medewerkers niet voldoende regelmogelijkheden hebben om aan alle aan hen gestelde eisen te voldoen. Werkstress is de lichamelijke en geestelijke toestand waarin iemand verkeert. Zoals veel andere onderzoekers (French \& Caplan, 1970; French et al., 1974; Kompier et al., 1996; Jones et al., 1998; Cox et al., 2000) gaan wij ervan uit dat werkstress een gevolg kan zijn van een situatie waarin gedurende een langere periode sprake is van werkdruk.

Dit artikel borduurt voort op het artikel van Smulders en Houtman (2004). Ook Smulders en Houtman gaan op zoek naar oorzaken van werkdruk. Het begrippenkader dat zij gebruiken, is hetzelfde als het begrippenkader dat in dit artikel wordt gebruikt. Smulders en Houtman concluderen dat de belangrijkste werkdrukvoorspellers zijn: complexiteit en onvoorspelbaarheid van het werk, zwaar en repeterend werk, emotioneel zwaar werk, beeldschermwerk en leidinggevend werk. Verderop in dit artikel zullen wij verder ingaan op deze resultaten. Het hier beschreven onderzoek verschilt echter op een belangrijk aspect van het onderzoek van Smulders en Houtman: de resultaten beschreven in dit artikel zijn gebaseerd op analyses uitgevoerd op een bestand van gegevens verzameld onder werkgevers (zie ook verder), terwijl Smulders en Houtman analyses uitvoerden op een bestand van gegevens verzameld onder werknemers.

\section{Hypothesen over de oorzaken van werkdruk}

Werkdruk neemt toe als er meer of complexer werk gedaan moet worden in hetzelfde tijdsbestek of als dezelfde hoeveelheid werk in minder tijd moet worden gedaan.

Er zijn verschillende factoren die van invloed kunnen zijn op de hoeveelheid werk en de tijd waarin dat werk gedaan moet worden. Die factoren liggen in de omgeving van organisa- ties, in ontwikkelingen die binnen organisaties plaatsvinden en in de kenmerken en de aard van het werk in organisaties.

\section{Omgevingshypothese}

Een eerste verklaring voor werkdruk in organisaties wordt gezocht in de kenmerken van de omgeving van organisaties. De hypothese (hypothese 1a) daarbij is dat: de werkdruk hoger zal zijn in organisaties die opereren in een instabiele en complexe omgeving.

De eisen die een omgeving stelt aan bedrijven en instellingen beïnvloeden de eisen die bedrijven en instellingen vervolgens aan hun medewerkers stellen. De complexiteit van het werk zal hoog zijn in een organisatie die in een complexe omgeving opereert. De voorspelbaarheid van het werk zal laag zijn in organisaties die opereren in een instabiele omgeving (zie ook Mintzberg, 1979; Wiezer, 1999). Op basis hiervan kan men veronderstellen dat de hoeveelheid regelproblemen en de complexiteit van deze problemen zal toenemen naarmate de omgeving complexer wordt. Daarmee neemt de hoeveelheid werk toe.

Het complexer worden van de omgeving heeft gevolgen voor de kwaliteit van de arbeid in organisaties, zo veronderstelt ook de European Foundation of Working and Living Conditions (Greenpaper, 1997). In opdracht van de European Foundation onderzochten Oeij en Wiezer (2002) wat de gevolgen zijn van de complexer wordende omgeving voor de kwaliteit van de arbeid in bedrijven in Europa. De resultaten van dit onderzoek ondersteunen de veronderstelling dat de taakeisen stijgen in organisaties die zich hebben moeten aanpassen aan de complexer wordende omgeving. Ook de resultaten van het onderzoek van Smulders en Houtman (2004) ondersteunen deze veronderstelling. De complexiteit en onvoorspelbaarheid van het werk (een gevolg - zo veronderstellen zij, en wordt ook hierboven verondersteld - van de complexiteit en onvoorspelbaarheid van de omgeving) blijken de belangrijkste factoren te zijn in de verklaring van werkdruk.

In een organisatie die opereert in een complexe en dynamische omgeving zullen meer regelproblemen voorkomen dan in organisaties die in een eenvoudige en stabiele omge- 
ving opereren. De mate waarin medewerkers regelmogelijkheden hebben, zal van invloed zijn op de werkdruk in deze organisaties. Regelmogelijkheden van medewerkers nemen toe naarmate de beslissingsbevoegdheid meer gedecentraliseerd is, en medewerkers (als groep) verantwoordelijk zijn voor het organiseren en verdelen van hun werk.

Hypothese $1 \mathrm{~b}$ luidt daarom: een complexe en instabiele omgeving leidt alleen tot werkdruk als medewerkers niet voldoende regelmogelijkheden hebben. Het effect van een complexe en instabiele omgeving zal wegvallen als ook de mate waarin regelmogelijkheden aanwezig zijn in beschouwing wordt genomen.

\section{Flexibiliseringhypothesen}

Ook flexibilisering binnen bedrijven heeft een effect op werkdruk. De hypothese (hypothese $2 \mathrm{a}$ en 2 b) hierbij is dat: in organisaties waar sprake is van functionele flexibilisering en/of van flexibilisering van tijden en contracten de werkdruk hoger zal zijn.

De argumentatie voor deze hypothese luidt als volgt:

De flexibiliteitdruk op ondernemingen leidt niet alleen tot een grotere behoefte aan flexibilisering, maar heeft ook geleid tot een verhoogde werkdruk voor werknemers, zo komt uit literatuur over flexibiliteit naar voren (Wood, 1988; Elger, 1991; Ackroyd \& Procter, 1998). De flexibiliteitdruk uit zich in hogere kwantitatieve eisen aan werknemers, in een grotere nadruk op efficiency en snelheid. Flexibiliteitdruk is een kenmerk van de omgeving van een organisatie, dat behalve een grote behoefte aan flexibiliteit in een organisatie ook werkdruk tot gevolg heeft. Interessant is om te onderzoeken of flexibilisering van organisaties zelf (los van de kenmerken van de omgeving) ook invloed heeft op werkdruk. Goudswaard (2003) zocht een antwoord op deze vraag. Zij onderzocht de effecten van verschillende vormen van flexibele arbeid op risico's voor werkdruk en stress. Op basis van literatuuronderzoek veronderstelde Goudswaard (2003) dat alle vormen van flexibele inzet van medewerkers leiden tot een verhoogd risico op mentale uitputting (als gevolg van werkstress) en dat dit in het bijzonder geldt voor medewerkers die verschillende vormen van flexibilisering combineren. $\mathrm{Zij}$ veronderstelde dat medewerkers die kwantitatief flexibel worden ingezet, door middel van flexibele arbeidstijden en flexibele contracten, vooral te maken hebben met een verhoging van kwantitatieve taakeisen (de hoeveelheid werk). Medewerkers die kwalitatief flexibel worden ingezet, bijvoorbeeld door middel van functionele flexibiliteit, hebben te maken met een verhoging van kwalitatieve taakeisen (de ingewikkeldheid van het werk). Functionele flexibiliteit wordt volgens Goudswaard (2003) over het algemeen in verband gebracht met veel regelmogelijkheden, terwijl contractflexibiliteit in verband wordt gebracht met weinig regelmogelijkheden. Goudswaard vond geen ondersteuning voor de hypothese dat kwantitatieve flexibiliteit gepaard gaat met hogere kwantitatieve taakeisen. De relatie tussen functionele flexibiliteit en hoge taakeisen wordt wel aangetoond.

\section{Onderbezettinghypothese}

Personele onderbezetting kan een belangrijke oorzaak zijn van werkdruk in een bedrijf. De hypothese (hypothese 3) hierbij is dat: de werkdruk hoger zal zijn in organisaties waar sprake is van personele onderbezetting.

Als dezelfde hoeveelheid werk met minder mensen moet worden gedaan dan gepland (personele onderbezetting), kan dat de werkdruk verhogen. Personele onderbezetting kan ontstaan als gevolg van een toegenomen vraag en een druk op de productie- en levertijden. Personele onderbezetting kan ontstaan doordat vacatures niet worden opgevuld, bijvoorbeeld omdat de sector door potentiële werknemers niet aantrekkelijk wordt gevonden of omdat bedrijven en instellingen als gevolg van de economische recessie het opvullen van vacatures uitstellen. Personele onderbezetting kan ook ontstaan door de invoering van deeltijdarbeid en kortere werktijden.

Smulders en Houtman (2004) veronderstellen dat onaantrekkelijk werk (zwaar werk, emotioneel belastend werk) een werkdrukstimulerende factor is omdat sectoren waar onaantrekkelijk werk wordt uitgevoerd moeite hebben om voldoende mensen aan te trekken (met onderbezetting als gevolg). Ze vinden 
inderdaad een relatie tussen onaantrekkelijk werk en werkdruk. In ons onderzoek zijn zowel gegevens over personele onderbezetting als gegevens over onaantrekkelijk werk meegenomen. Hier wordt verondersteld dat beide factoren, los van elkaar, een effect hebben op werkdruk.

\section{Vernieuwings- en reorganisatiehypothese}

Het invoeren van nieuwe werkmethoden en technieken en het doorvoeren van reorganisaties zal de werkdruk in bedrijven (tijdelijk) verhogen. De hypothese luidt (hypothese 4): werkdruk zal hoger zijn in organisaties waar interne reorganisaties en procesvernieuwingen hebben plaatsgevonden.

Een andere oorzaak van werkdruk die Smulders en Houtman (2004) noemen, is de voortgaande invoering van nieuwe werkmethoden en technieken die mensen zich eigen moeten maken. Daaraan zou toegevoegd kunnen worden dat interne reorganisaties op zichzelf ook kunnen leiden tot een (tijdelijke) verhoging van de taakeisen. Het je eigen maken van nieuwe werkmethoden en technieken kost tijd. 'Kinderziektes' kunnen tijdelijk voor extra regelproblemen zorgen. Ook een reorganisatie kost tijd, tijd om de nieuwe organisatie goed vorm te geven, tijd om eventuele 'kinderziektes' te overwinnen en tijd om in de nieuwe organisatievorm optimaal te kunnen opereren.

Smulders en Houtman operationaliseren het begrip 'nieuwe werkmethoden en technieken' met een vraag naar de hoeveelheid beeldschermwerk en het gebruik van mobiele telefoon, fax, e-mail en internet. De hoeveelheid beeldschermwerk blijkt positief samen te hangen met werkdruk. Het gebruik van mobiele telefoon, fax, e-mail en internet lijkt juist werkdrukverlagend te zijn. Hiermee wordt de hypothese maar deels ondersteund.

\section{Arbo- en werkinhoudhypothese}

Daarnaast kan een deel van de verschillen in werkdruk tussen organisaties verklaard worden door de (andere) kenmerken van het werk in de organisatie. De hypothese (hypothese 5) hierbij is dat: werkdruk hoger zal zijn in organisaties waarin veel relatief onaantrekkelijk werk wordt verricht.
Smulders en Houtman (2004) signaleren dat relatief onaantrekkelijk werk werkdrukbevorderend kan zijn, bijvoorbeeld omdat het een sector onaantrekkelijk maakt voor potentiële nieuwe medewerkers en het voor organisaties moeilijker is om tot een passende bezetting te komen. Zij vinden ondersteuning voor deze hypothese. In dit onderzoek worden zwaar fysiek werk en onderbezetting allebei als variabelen meegenomen. Verondersteld wordt dat zwaar fysiek werk, los van onderbezetting, werkdruk veroorzaakt. Naarmate het werk fysiek zwaarder wordt, worden de hersteltijden langer. Fysiek zwaar werk kost tijd, en verhoogt daardoor de tijdsdruk.

\section{Samenhang tussen oorzaken van werkdruk}

De oorzaken van werkdruk die hierboven zijn beschreven, hebben elk zelfstandig een veronderstelde relatie met werkdruk, maar hangen ook met elkaar samen. Een complexe en instabiele omgeving zal steeds wisselende eisen stellen aan de organisatie. Organisaties zullen daarop reageren met reorganisaties en procesvernieuwingen. De flexibiliteitbehoefte - zo werd hierboven al verondersteld - zal door veranderende eisen toenemen. Organisaties zullen daarop reageren met een toename van flexibilisering binnen de organisatie.

Een toegenomen complexiteit van de omgeving zal het werk in organisaties ook complexer maken. Het aandeel 'hoofdarbeid' zal stijgen ten opzichte van het aandeel 'handarbeid'. Het percentage medewerkers dat onaantrekkelijk werk doet (fysiek zwaar werk, eentonig werk), zal dalen naarmate de complexiteit en onvoorspelbaarheid van de omgeving van een organisatie toenemen.

Door de wisselende eisen die aan de organisatie worden gesteld, kunnen ook de eisen die aan medewerkers worden gesteld, veranderen. Dit zou kunnen leiden tot een tijdelijke (kwalitatieve) onderbezetting.

\section{Onderzoeksvragen}

Op basis van het bovenstaande zijn voor dit artikel de volgende hypothesen getoetst:

1a De werkdruk zal hoger zijn in organisaties met een instabiele en complexe omgeving.

$1 b$ Een complexe en instabiele omgeving leidt alleen tot werkdruk als medewer- 
kers niet voldoende regelmogelijkheden hebben. Het effect van de omgevingsfactoren zal wegvallen als de mate waarin regelmogelijkheden aanwezig zijn in beschouwing wordt genomen.

$2 a$ In organisaties waar sprake is van functionele flexibilisering, zal de werkdruk hoger zijn.

$2 b$ In organisaties waar sprake is van flexibilisering van tijden en contracten, zal de werkdruk hoger zijn.

3 De werkdruk zal hoger zijn in organisaties waar sprake is van personele onderbezetting.

4 De werkdruk zal hoger zijn in organisaties waar interne reorganisaties en procesvernieuwing hebben plaatsgevonden.

5 De werkdruk zal hoger zijn in organisaties waarin veel relatief onaantrekkelijk werk wordt verricht.

\section{Methode van onderzoek en variabelen}

De onderzoeksvragen zijn beantwoord met behulp van gegevens verzameld in het Organisatie voor Strategisch Arbeidsmarktonderzoek (OSA)-arbeidsvraagpanel, zevende golf. Deze gegevens zijn verzameld in 2001. In het totaal zijn gegevens gebruikt van 3.199 bedrijven. Het OSA-arbeidsvraagpanel is een tweejaarlijks onderzoek onder een steekproef van Nederlandse arbeidsorganisaties met minstens vijf werknemers. De gegevens zijn verzameld op het niveau van de vestiging. De dataverzameling heeft zowel mondeling als schriftelijk plaatsgevonden. In dit onderzoek zijn vooral de gegevens gebruikt die werden verzameld door middel van mondelinge interviews. Bij de analyses van de gegevens is gebruikgemaakt van weegfactoren, om gevolgen van stratificering van de steekproef te beperken. Hierdoor is het mogelijk cijfers te presenteren die representatief zijn voor de populatie van Nederlandse arbeidsorganisaties met vijf of meer medewerkers (Fouarge et al., 2001). Hieronder worden de variabelen beschreven die in de analyses zijn gebruikt.

Werkdruk wordt over het algemeen benaderd vanuit het werknemersperspectief. In de meeste onderzoeken worden gegevens geanalyseerd, verzameld onder werkenden in Nederland of Europa (zie CBS, 2001; TNO
Arbeid Survey (TAS) en de onderzoeken van de European Foundation). De gegevens voor het OSA-arbeidsvraagpanel zijn verzameld onder werkgevers (directeuren, bedrijfsleiders, managers, P\&O'ers, administrateurs). Het is mogelijk dat werkgevers een andere inschatting maken van werkdruk in hun bedrijf dan werknemers dat zouden doen. Deze verschillen zouden de resultaten van de in dit artikel beschreven analyses kunnen beïnvloeden. Derhalve onderzoeken we kort de eventuele verschillen in inschatting van werkdruk door werkgevers en werknemers. Omdat we niet beschikken over een dataset van gegevens van werknemers van de in het OSA-panel ondervraagde werkgevers, of over een dataset van antwoorden van werknemers op dezelfde vragenset als door het OSA-panel is gebruikt, is deze vergelijking slechts indicatief en kunnen we niet meer doen dan een aantal cijfers naast elkaar zetten.

\section{Verschilt de hoeveelheid werkdruk volgens werkgevers van de hoeveelheid werkdruk vol- gens werknemers?}

In het onderzoek van de European Foundation (Paoli, 2001) is medewerkers de vraag gesteld: 'Moet u meer dan 50 procent van uw werktijd werken in een hoog tempo?' In 2000 beantwoordde 43 procent van de Nederlandse medewerkers deze vraag met ' $\mathrm{ja}$ '.

De OSA heeft werkgevers gevraagd aan te geven hoeveel procent van hun medewerkers regelmatig onder tijdsdruk werkt. Dat percentage is iets hoger dan het gemiddelde percentage medewerkers dat aangeeft in een hoog tempo te moeten werken $(46 \%)$. Als we voor het gemak even veronderstellen dat iemand die onder tijdsdruk werkt dat (ook) percipieert als werken in een hoog tempo, dan kunnen we vaststellen dat de inschatting van werkgevers over de werkdruk van hun medewerkers niet zoveel afwijkt van de inschatting die medewerkers zelf maken van hun eigen werkdruk.

In de Enquête Beroeps Bevolking (EBB) is medewerkers ook gevraagd of ze onder tijdsdruk werken. In dit onderzoek kregen medewerkers de mogelijkheid een onderscheid te maken tussen regelmatig onder tijdsdruk werken en soms onder tijdsdruk werken. Gemiddeld 33 procent van de medewerkers geeft aan regelmatig onder tijdsdruk te wer- 
ken. Dit percentage is lager dan het percentage medewerkers dat volgens hun werkgevers regelmatig onder tijdsdruk werkt $(46 \%)$.

Hoewel het met de gegevens die beschikbaar zijn niet mogelijk is een goede, wetenschappelijk verantwoorde vergelijking te maken tussen 'werkdruk volgens werknemers' en 'werkdruk volgens werkgevers', lijken de verschillen niet zo groot dat ze een deel van de resultaten van dit onderzoek zouden kunnen verklaren.

\section{Afhankelijke variabele werkdruk}

Werkdruk is in dit onderzoek de 'te verklaren variabele'. Voor de analyses in dit artikel hebben we, om werkdruk te meten, gebruikgemakkt van het item '\% medewerkers dat volgens de werkgever in het bedrijf regelmatig te maken heeft met werk onder tijdsdruk'.

Dit item hangt samen met de typering van werkdruk. In organisaties waar de werkgevers de werkdruk als hoog typeren, heeft een significant hoger percentage medewerkers te maken met werk onder hoge tijdsdruk (64\%) dan in organisaties waar de werkgevers de werkdruk als 'laag of niet hoog/niet laag' typeren $(23 \%$ en $9 \%)$. Om de analyses niet te ingewikkeld te maken, is gekozen voor één outputmaat: werken onder tijdsdruk (kwantitatieve werkdruk).

\section{Onafhankelijke variabelen}

\section{1a Omgevingskenmerken}

De druk vanuit de omgeving op een organisatie zal groter zijn en de complexiteit van de omgeving zal toenemen als een organisatie opereert in een markt met concurrenten. De onvoorspelbaarheid van de omgeving kan toenemen als die omgeving de landsgrenzen overschrijdt. Verwacht wordt dat de export van goederen of diensten de tijdsdruk in een organisatie zal verhogen. De gevoeligheid van de organisatie voor economische schommelingen is een kenmerk van de organisatie en niet van de omgeving. Als controlevariabele is deze variabele toch meegenomen in de analyse naar de invloed van omgevingsvariabelen op werkdruk.

Tabel 1 Variabelen gebruikt in het onderzoek

N Min. Max. Mean $\begin{gathered}\text { Std. } \\ \text { Deviation }\end{gathered}$

\section{Werkdruk}

Percentage werknemers dat regelmatig te maken heeft met werk onder tijdsdruk

$\begin{array}{lllll}2.862 & 0 & 100 & 45,97 & 34,66\end{array}$

(...\%)

\section{Omgevingskenmerken}

Zijn door deze organisatie in 2000 producten of diensten geëxporteerd?

( $1=\mathrm{ja}, 2$ = nee)

Is bij deze organisatie sprake van een markt

met concurrentie?

$(1=\mathrm{ja}, 2=$ nee $)$

Is deze organisatie gevoelig voor schommelingen

in de economische conjunctuur?

$\begin{array}{ccccc}1.712 & 1 & 2 & 1,68 & 0,47 \\ 2.765 & 1,00 & 2,00 & 1,2383 & 0,4261 \\ 2.939 & 1 & 3 & 2,22 & 0,75\end{array}$

( $1=j a$, in sterke mate, $2=j a$, enigzins,

$3=$ niet of nauwelijks)

\section{Regelmogelijkheden}

Hoeveel hiërarchische of leidinggevende niveaus heeft de organisatie?

(...niveaus) 
De invloed van organisatiekenmerken op werkdruk in organisaties

Vervolg Tabel 1

\begin{tabular}{|c|c|c|c|c|c|}
\hline & $N$ & Min. & Max. & Mean & $\begin{array}{c}\text { Std. } \\
\text { Deviation }\end{array}$ \\
\hline $\begin{array}{l}\text { Is er sprake van autonome taakgroepen waarbinnen } \\
\text { werknemers zelf voor een belangrijk deel het werk } \\
\text { kunnen organiseren en verdelen (regelmogelijkheden)? } \\
(1=j a, 2=\text { nee) }\end{array}$ & 2.936 & 1 & 2 & 1,38 & 0,48 \\
\hline $\begin{array}{l}\text { Welk percentage is binnen deze organisatie direct } \\
\text { betrokken bij de kernactiviteiten? } \\
(\ldots \%)\end{array}$ & 2.863 & 0 & 358 & 75,19 & 23,48 \\
\hline \multicolumn{6}{|l|}{ Flexibilisering } \\
\hline $\begin{array}{l}\text { Hoeveel procent van de werknemers heeft te maken } \\
\text { met flexibele jaarroosters? } \\
\text { (het aantal arbeidsuren per jaar ligt vast, de } \\
\text { werkgever bepaalt binnen zekere grenzen } \\
\text { in welke perioden meer of minder wordt gewerkt) } \\
(\ldots \%)\end{array}$ & 2.824 & 0 & 100 & 13,77 & 29,01 \\
\hline $\begin{array}{l}\text { Hoeveel procent van de werknemers werkt op } \\
\text { afroepbasis (opgeroepen om te werken afhankelijk } \\
\text { van de drukte)? } \\
(\ldots \%)\end{array}$ & 2.837 & 0 & 100 & 4,18 & 11,59 \\
\hline $\begin{array}{l}\text { Is er in deze organisatie sprake van taak of functie- } \\
\text { roulatie, dat wil zeggen dat werknemers zonder } \\
\text { omschakeltijd elkaars werk overnemen? } \\
(1=\mathrm{ja}, 2=\text { nee })\end{array}$ & 2.937 & 1 & 2 & 1,34 & 0,47 \\
\hline $\begin{array}{l}\text { Hoeveel procent van de werknemers werkt in } \\
\text { wisselende diensten, bijvoorbeeld avond, nacht } \\
\text { en/of weekenddiensten? } \\
(\ldots \%)\end{array}$ & 2.837 & 0 & 100 & 24,80 & 32,45 \\
\hline \multicolumn{6}{|l|}{ Onderbezetting } \\
\hline $\begin{array}{l}\text { Was er in } 2000 \text { wat betreft de inzet van arbeid sprake } \\
\text { van onderbezetting (te weinig werknemers), } \\
\text { overbezetting (te veel werknemers), of van een min of } \\
\text { meer passende bezetting? } \\
\text { ( } 1=\text { onderbezetting, } 3 \text { = overbezetting, } 2 \text { = min of meer pa }\end{array}$ & 2.937 & zetting 1 & 3 & 1,65 & 0,56 \\
\hline \multicolumn{6}{|l|}{ Vernieuwingen en reorganisaties } \\
\hline $\begin{array}{l}\text { Ten slotte ben ik geïnteresseerd in de procesvernieuwing, } \\
\text { dus de vernieuwing van het productie- of dienstver- } \\
\text { leningsproces binnen deze organisatie. } \\
\text { Is er de afgelopen twee jaar een ingrijpende verandering } \\
\text { geweest in het productie- of dienstverleningsproces, } \\
\text { bijvoorbeeld door de introductie van een belangrijke } \\
\text { nieuwe techniek? } \\
(1=\text { ja, } 2 \text { = nee) }\end{array}$ & 2.883 & 1 & 2 & 1,58 & 0,49 \\
\hline $\begin{array}{l}\text { Hebben binnen deze organisatie de afgelopen twee } \\
\text { jaar interne reorganisaties plaatsgevonden? } \\
(1=\mathrm{ja}, 2=\mathrm{nee})\end{array}$ & 2.930 & 1 & 2 & 1,55 & 0,50 \\
\hline
\end{tabular}

234 Tijdschrift voor Arbeidsvraagstukken 2005-21, nr. 3 


\begin{tabular}{|c|c|c|c|c|c|}
\hline & $N$ & Min. & Max. & Mean & $\begin{array}{c}\text { Std. } \\
\text { Deviation }\end{array}$ \\
\hline \multicolumn{6}{|l|}{ Arbo en werkinhoud } \\
\hline $\begin{array}{l}\text { Hoeveel procent van de werknemers heeft regelmatig } \\
\text { te maken met lichamelijk zwaar werk? } \\
(\ldots \%)\end{array}$ & 2.859 & 0 & 100 & 26,46 & 30,98 \\
\hline $\begin{array}{l}\text { Kunt } u \text { aangeven wat de gemiddelde inwerktijd is } \\
\text { voor een nieuwe werknemer voor de meest } \\
\text { voorkomende functie? } \\
\text { ( } 1=\text { minder dan een week, } 2=\text { van } 1 \text { week tot } 1 \text { maand, } \\
3=\text { van } 1 \text { maand tot } 1 \text { jaar, } 4=\text { meer dan } 1 \text { jaar) }\end{array}$ & 2.899 & 1 & 4 & 2,56 & 0,69 \\
\hline $\begin{array}{l}\text { Hoeveel procent van de werknemers heeft regelmatig } \\
\text { te maken met eentonig werk? } \\
(\ldots \%)\end{array}$ & 2.834 & 0 & 100 & 7,74 & 15,56 \\
\hline \multicolumn{6}{|l|}{ Bedrijfsgrootte } \\
\hline $\begin{array}{l}\text { Hoeveel werknemers waren er bij deze organisatie in } \\
\text { december } 2000 \text { in dienst (alleen personeel meetellen } \\
\text { dat eind } 2000 \text { op uw loonlijst stond)? }\end{array}$ & 2.944 & 5 & 18.478 & 915,59 & $2.271,62$ \\
\hline I_I_I_I_I_l werknemers & & & & & \\
\hline
\end{tabular}

1 Een aantal antwoordcategorieën is gehercodeerd voor de regressieanalyse. In de tabel met de resultaten van deze analyse staan de nieuwe antwoordcategorieën.

\section{1b Regelmogelijkheden}

Regelmogelijkheden nemen toe naarmate beslissingsbevoegdheid meer gedecentraliseerd is (Vaas et al., 1995; Peeters, 1995). De dataset bevat een aantal variabelen waarmee decentralisatie kan worden gemeten:

Gevraagd wordt naar het aantal hiërarchische lagen in het bedrijf. Er is ook gevraagd naar het percentage medewerkers dat zich bezighoudt met het primaire proces. Ook dit kan een indicatie zijn voor de mate van decentralisatie. Een hoog percentage directe medewerkers betekent relatief weinig 'stafmedewerkers'. Een grote stafafdeling duidt meestal op een grote mate van 'standaardisatie van werkprocessen'.

Een ultieme vorm van decentralisatie is het werk organiseren in autonome taakgroepen. Ook naar het bestaan van autonome taakgroepen is gevraagd in het OSA-panel. Autonome taakgroepen zijn in de vragenlijst omschreven als '[groepen] waarbinnen medewerkers zelf voor een belangrijk deel het werk kunnen organiseren en verdelen'.
Om te onderzoeken of de interactie tussen complexiteit van de omgeving en regelmogelijkheden een deel van de variantie in werkdruk verklaart, is een interactieterm in de analyse opgenomen. Deze interactieterm is samengesteld uit de variabele 'markt met concurrenten' en de variabele 'aantal hiërarchische lagen'. Voor de eerste variabele is gekozen, omdat verondersteld wordt dat een markt met concurrenten de complexiteit van de omgeving van een organisatie het meest direct beïnvloedt. De operationalisering van de variabele autonome taakgroepen is voor discussie vatbaar. Het percentage directe medewerkers blijkt niet significant (zie ook verder). Gekozen is voor het aantal hiërarchische lagen.

\section{Mate van flexibilisering}

In de literatuur wordt een onderscheid gemaakt tussen kwalitatieve en kwantitatieve flexibilisering. Kwalitatieve flexibiliteit is in dit onderzoek gemeten met de vraag of er in deze organisatie sprake is van taak- of functieroulatie. Taak- of functieroulatie wordt dan 
gedefinieerd als: 'dat werknemers zonder omschakeltijd elkaars werk overnemen'.

Kwantitatieve flexibiliteit wordt in dit onderzoek geoperationaliseerd door drie vragen: a) het percentage medewerkers dat werkt met een afroepcontract (dat wil zeggen ze worden opgeroepen om te werken afhankelijk van de drukte), b) het percentage medewerkers dat werkt met een flexibel jaarrooster (het aantal arbeidsuren ligt vast, de werkgever bepaalt wanneer er meer of minder gewerkt moet worden) en c) het aantal medewerkers dat werkt in wisselende diensten (avond-, nacht- en/of weekenddiensten). De bedrijfstijd per week is als controlevariabele in de analyse meegenomen.

\section{Onderbezetting}

Aan respondenten is de vraag voorgelegd of er in 2000 sprake was van 'onderbezetting' (te weinig werknemers), 'overbezetting' (te veel werknemers) of 'min of meer passende bezetting'. De antwoordcategorieën zijn gehercodeerd, waarbij het antwoord 'onderbezetting' score $1 \mathrm{kreeg}$, het antwoord 'min of meer passende bezetting' score 2 en het antwoord 'overbezetting' score 3.

\section{Vernieuwingen en reorganisaties}

De antwoorden op de vraag 'hebben er binnen deze organisatie de afgelopen twee jaar interne reorganisaties plaatsgevonden?' zijn in de analyses meegenomen om de invloed van interne reorganisaties op werkdruk te kunnen onderzoeken.

De invoering van nieuwe werkmethoden en technieken is geoperationaliseerd door middel van de vraag naar procesvernieuwing. Procesvernieuwing wordt in de vragenlijst gedefinieerd als 'de vernieuwing van het productie- of dienstverleningsproces binnen deze organisatie'.

\section{Arbo en werkinhoud}

Behalve werkdruk zijn nog andere kenmerken van het werk in de organisatie onderzocht. De respondenten is ook gevraagd aan te geven hoeveel procent van hun medewerkers regelmatig te maken heeft met fysiek zwaar werk en hoeveel procent van hun medewerkers regelmatig te maken heeft met eentonig werk. Het niveau van de functies in bedrijven is gemeten aan de hand van de inwerktijd voor de meest voorkomende functies in het bedrijf.
Om te onderzoeken of de interactie tussen onderbezetting en onaantrekkelijk werk een deel van de variantie in werkdruk verklaart, is een interactieterm in de analyse opgenomen. Deze interactieterm is samengesteld uit de variabele 'onderbezetting' en 'fysiek zwaar werk'. De veronderstelling dat onaantrekkelijk werk kan leiden tot onderbezetting en daardoor tot werkdruk, is afgeleid van het onderzoek van Smulders en Houtman (2004). Zij operationaliseren onaantrekkelijk werk door fysiek zwaar werk. Voor de interactieterm is daarom ook hier gekozen voor fysiek zwaar werk.

\section{Controlevariabelen}

\section{Bedrijfsgrootte}

Om te onderzoeken of de omvang van bedrijven de relaties beïnvloedt, is de variabele schaalgrootte meegenomen in de analyses.

Schaalgrootte wordt in deze analyse gemeten door middel van het aantal medewerkers in dienst.

\section{Sector}

Voor de variabele sector zijn dummyvariabelen gemaakt. Deze dummyvariabelen zijn (allemaal steeds op één na) meegenomen in de analyses om de invloed die sectoren hebben op de verbanden tussen variabelen mee te wegen. De sector Onderwijs is de referentiecategorie voor de bedrijfstakken.

De onderzochte relaties worden in figuur 1 samengevat.

\section{Analyses}

Om de oorzaken van werkdruk te bepalen hebben we gebruikgemaakt van lineaire regressieanalyse. De vraag die we met deze analyses hebben beantwoord, is de vraag hoe verschillen in werkdruk tussen bedrijven verklaard kunnen worden. Het item waarmee werkdruk is gemeten is een continue variabele. De overige variabelen waarmee werkdruk of kenmerken van werkdruk in kaart gebracht zijn, zijn van categoriaal niveau en daarom minder geschikt als resultaatvariabele voor een lineaire regressieanalyse. In de analyses zijn twee variabelen als 'controlevariabelen' meegenomen, om de invloed die deze variabelen hebben op de verbanden te onderzoeken. Daarnaast zijn twee interactietermen meegenomen. 


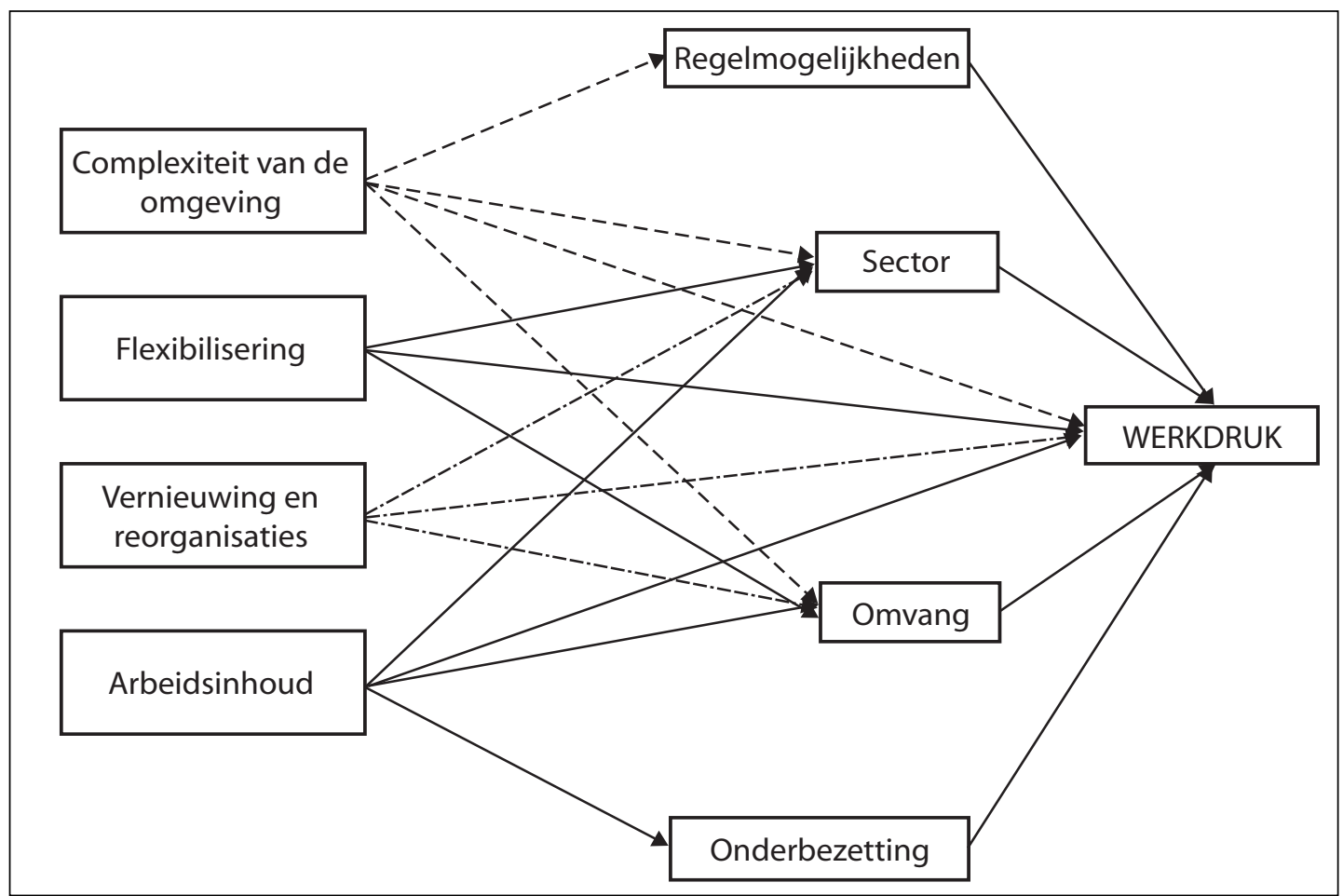

Figuur 1 Onderzochte relaties

\section{Resultaten}

Welke factoren beïnvloeden werkdruk in organisaties?

In tabel 2 worden de resultaten weergegeven van de lineaire regressieanalyse. Met deze analyse zijn de hypothesen getoetst.

\section{Verklaring voor de variantie in werken onder} tijdsdruk; bespreking van de hypothesen

De resultaten van de regressieanalyse ondersteunen nagenoeg alle hier geformuleerde hypothesen.

\section{Hypothese 1: Omgevingskenmerken en regel- mogelijkheden}

De variabelen waarmee de complexiteit en instabiliteit van de omgeving zijn gemeten, zijn allebei significante voorspellers van werkdruk. De werkdruk stijgt naarmate bedrijven meer te maken hebben met markten in het buitenland (export van goederen en diensten) en met concurrentie op de markt.

De veronderstelling dat deze variabelen geen significante voorspellers meer zijn als de mate waarin medewerkers over regelmogelijkheden beschikken meegenomen wordt, wordt niet ondersteund. Het interactie-effect tussen complexiteit van de omgeving en regelmogelijkheden is niet significant. Niet alle relaties zijn in de voorspelde richting. De werkdruk stijgt naarmate er minder hiërarchische lagen zijn (een teken van decentralisatie). Maar de werkdruk stijgt ook in bedrijven waar autonome taakgroepen ingevoerd zijn. Dit resultaat is onverwacht. In de discussie zullen we hier verder op ingaan. Het percentage medewerkers dat zich bezighoudt met het primaire proces (een indicatie van de omvang van stafafdelingen) is geen significante voorspeller van werkdruk.

\section{Hypothese 2: mate van flexibilisering}

Zowel kwantitatieve flexibilisering (afroepcontracten en flexibele jaarroosters) als kwalitatieve flexibilisering (taak- of functieroulatie) is een significante voorspeller van werkdruk. Naarmate de flexibilisering stijgt, stijgt ook de werkdruk. 
De invloed van organisatiekenmerken op werkdruk in organisaties

Tabel 2 Resultaten regressieanalyse

Afhankelijke variabele: \% medewerkers dat werkt onder tijdsdruk

Bèta's

\section{Omgeving van de organisatie}

Export van producten of diensten 2000 ( $\mathrm{ja}=1$, nee $=0$ )

$0,07^{*}$

Voor organisatie sprake een markt + concurrentie $(j a=1$, nee $=0$ )

$0,07^{* *}$

Gevoelig voor economische schommelingen (ja in sterke mate $=2$,

Ns

enigszins $=1$, niet of nauwelijks $=0$ )

\section{Regelmogelijkheden}

Aantal hiërarchische niveaus

Autonome taakgroepen ( $\mathrm{ja}=1$, nee $=0$ )

$\%$ directe werknemers

$\left(0,06^{* *}\right) / \mathrm{Ns}$

$0,05^{* *}$

Omgeving * regelmogelijkheden (interactieterm)

Ns

Ns

\section{Mate van flexibilisering}

$\%$ werknemers met een flexibel jaarrooster

$0,07^{* *}$

$\%$ werknemers met een afroepcontract

$0,07 * *$

Sprake van taak- of functieroulatie $(\mathrm{ja}=1$, nee $=0$ )

$0,04^{*}$

$\%$ werknemers met wisselende diensten

Ns

\section{Onderbezetting}

Onderbezetting

Ns

Vernieuwing en reorganisatie

Procesvernieuwing ( $\mathrm{ja}=1$, nee $=0$ )

Reorganisaties ( $\mathrm{ja}=1$, nee $=0$ )

$0,10 * * *$

Ns

\section{Arbo- en werkinhoud}

$\%$ medewerkers lichamelijk zwaar werk

$0,22 * * *$

Inwerktijd meest voorkomende functie

$0,16 * * *$

$\%$ medewerkers eentonig werk

$0,06^{* *}$

Onderbezetting* Fysiek zwaar werk

Ns

\section{Controlevariabelen}

Aantal medewerkers

Industrie

Ns

Bouw

Ns

Handel

Ns

Transport

Ns

Zakelijke dienstverlening

Ns

Zorg en welzijn

Ns

Overige dienstverlening

Ns

Overheid

Ns

Percentage verklaarde variantie (Adj R2)

$* p<0,10$

** $p<0,05$

$* * * \mathrm{p}<0,01, \mathrm{~N}=1712$

$\mathrm{Na}$ het toevoegen van de interactieterm tussen compexiteit en regelmogelijkheden is de variabele aantal hiërarchische niveaus niet meer significant. 


\section{Hypothese 3: onderbezetting}

De veronderstelling dat onderbezetting leidt tot werkdruk wordt niet ondersteund. De correlatie tussen onderbezetting en werkdruk is wel significant $\left(\mathrm{r}=0,13^{\star \star}\right)$, maar deze variabele blijkt geen significante voorspeller meer als andere variabelen in de vergelijking worden meegenomen.

\section{Hypothese 4: vernieuwingen en reorganisaties}

De variabele reorganisatie blijkt geen significante voorspeller voor werkdruk, maar de variabele procesvernieuwing wel. In situaties waarin sprake is van procesvernieuwing, is de werkdruk hoger.

\section{Hypothese 5: Arbo en werkinhoud}

Ook de veronderstelling dat de werkinhoud een rol speelt in de verklaring van werkdruk wordt ondersteund. Naarmate meer sprake is van lichamelijk zwaar werk, stijgt de werkdruk. Dat geldt ook voor eentonig werk: de werkdruk stijgt naarmate meer medewerkers eentonig werk verrichten. De werkdruk stigt ook naarmate het functieniveau (de inwerktijd voor de meest voorkomende functies) in het bedrijf stijgt.

De interactieterm tussen zwaar werk en onderbezetting is geen significantie voorspeller van werkdruk.

Aan de bètawaarden kan afgelezen worden 'hoe zwaar' de variabelen meewegen in de verklaring van variantie in werkdruk. Als de in het inhoudelijke deel gepresenteerde verklaringen op een rijtje worden gezet (van belangrijk naar minder belangrijk) ziet dat er als volgt uit:

1werkinhoud (vooral zwaar werk en inwerktijd);

2 procesvernieuwingen;

3 complexiteit en instabiliteit van de omgeving;

4 mate van flexibilisering (vooral kwantitatieve flexibilisering);

5 regelmogelijkheden.

In de analyses is een aantal controlevariabelen meegenomen. De variabelen uit het model blijven significante voorspellers van werkdruk, ook als de controlevariabelen 'omvang van het bedrijf' en 'sector' meegenomen worden in de analyses. De omvang van het bedrijf zelf blijkt ook een significante voorspeller van werkdruk. Werkdruk stijgt naarmate bedrijven groter zijn. De variabelen voor de verschillende sectoren lijken geen significante voorspellers voor werkdruk te zijn. Verschillen tussen sectoren kunnen dus verklaard worden door de andere variabelen in dit onderzoek. De significantie van sectoren verdwijnt op het moment dat de omgevingsvariabelen in de analyse worden meegenomen.

\section{Samenvatting en discussie}

In dit artikel is onderzocht welke factoren werkdruk in bedrijven kunnen beïnvloeden. We bespreken de meest opvallende resultaten.

\section{Hypothese 1}

Het resultaat dat werkdruk stigt naarmate de omgeving van een organisatie complexer en instabieler is, hadden we verwacht. Smulders en Houtman (2004) vonden hetzelfde resultaat. Wat interessant is, is het feit dat deze variabelen significante voorspellers blijven, ook als de mate waarin regelmogelijkheden aanwezig zijn, wordt meegenomen. Voor een mogelijk effect van de interactie tussen complexiteit van de omgeving en regelmogelijkheden is geen bewijs gevonden.

Over het algemeen wordt gesteld dat decentralisatie van verantwoordelijkheden en beslissingsbevoegdheid de meest succesvolle reactie is van een bedrijf op toename van complexiteit en instabiliteit in de markt (zie ook Bolwijn \& Kumpe, 1990). Toch blijkt uit dit onderzoek dat omgevingsfactoren een rol spelen, ongeacht de aanwezigheid van regelmogelijkheden. Het is dus niet helemaal mogelijk de werkdrukrisico's die de omgeving veroorzaakt weg te filteren. In dit artikel wordt verondersteld dat een complexe omgeving het werk van mensen complexer maakt. De onderliggende veronderstelling is dat complexiteit en instabiliteit van de omgeving van invloed zijn op de hoeveelheid en aard van de regelproblemen waar medewerkers mee geconfronteerd worden. Deze veronderstelling is niet getoetst, regelproblemen zijn niet in het onderzoek meegenomen. Als deze veronderstelling niet 
juist is, en de omgevingsvariabelen geen effect hebben op de regelproblemen van medewerkers, is dat een verklaring voor het feit dat de aanwezigheid van regelmogelijkheden de relatie tussen omgevingskenmerken en werkdruk niet verandert.

En zelfs als complexiteit en instabiliteit wel een effect hebben op regelproblemen die zich in een organisatie voordoen, dan is het nog maar de vraag op welk niveau deze regelproblemen zich voordoen. In dit onderzoek wordt verondersteld dat deze regelproblemen zich voordoen op het niveau van werknemers, maar het zou ook heel goed zo kunnen zijn dat deze regelproblemen alleen op directieniveau, of in bepaalde afdelingen manifest zijn.

Daarnaast worden regelmogelijkheden geoperationaliseerd door het aantal hiërarchische lagen en door het voorkomen van autonome taakgroepen. Ook hieraan liggen veronderstellingen ten grondslag. Als het aantal hiërarchische lagen in een organisatie minder groot is, zal een deel van de verantwoordelijkheden en beslissingsbevoegdheden gedelegeerd worden naar een lager niveau. Verondersteld wordt dat dit betekent dat medewerkers op dat lagere niveau dan ook meer mogelijkheden hebben om regelproblemen op te lossen, maar ook deze veronderstelling is niet getoetst. Decentralisatie is een voorwaarde voor autonomie, maar is niet hetzelfde als autonomie. Bovendien is het maar de vraag of de regelmogelijkheden die medewerkers krijgen door decentralisatie, wel de (regel)mogelijkheden zijn die ze nodig hebben om de voorkomende regelproblemen op te lossen. Daarnaast zijn de twee andere regelmogelijkheden (de mogelijkheid om met collega's problemen op te lossen en de mogelijkheid om via overleg problemen op te lossen, zie Vaas et al., 1995) niet in dit onderzoek meegenomen. Ook informatievoorziening, een van de belangrijkste factoren voor preventie van werkdruk, is niet in dit onderzoek meegenomen.

In tegenstelling tot wat verwacht werd, blijkt de werkdruk hoger te zijn in organisaties waar autonome taakgroepen voorkomen. Een belangrijke verklaring voor dit resultaat kan de wijze zijn waarop de aanwezigheid van autonome taakgroepen gemeten is. Autonome taakgroepen zijn in de vragen- lijst omschreven als: [groepen] waarbinnen medewerkers zelf voor een belangrijk deel het werk kunnen organiseren en verdelen. Met deze formulering wordt geen onderscheid gemaakt tussen verschillende vormen van (semi-autonome) taakgroepen die in de literatuur worden onderscheiden. Deze vormen verschillen vooral in mate van decentralisatie. Fröhlich en Pekruhl (1996) tonen aan dat autonome taakgroepen in de meest gedecentraliseerde vorm (het Scandinavian model) in 1996 in ongeveer 5 procent van de bedrijven in Nederland voorkwam. Op de vraag of autonome taakgroepen zoals hierboven door het OSA gedefinieerd in de organisatie voorkomt, antwoordt ruim 65 procent van de bedrijven ' $\mathrm{ja}$ '. Dat doet vermoeden dat alle vormen van taakgroepen als autonome taakgroep beschouwd zijn.

Landsbergis, Schnall en Cahill (1999) hebben in verschillende onderzoeken naar de gezondheidseffecten van 'lean production' en vergelijkbare systemen aangetoond dat 'lean production'-systemen de werkdruk in bedrijven verhogen. Ook in het lean-productionsysteem wordt gebruikgemaakt van taakgroepen. Deze taakgroepen lijken echter veel meer op de door Fröhlich en Pekruhl onderscheiden 'Toyota/Lean Production model'taakgroepen. In deze taakgroepen gaat een verhoging van taakeisen niet gepaard met een verhoging van de regelmogelijkheden, zo stelt Landsbergis.

Taakgroepen blijven echter een significante voorspeller van werkdruk, ook als de mate van decentralisatie in de vergelijking wordt meegenomen. Dat betekent dat er kenmerken van taakgroepen zijn, anders dan de mate van decentralisatie, die werkdruk beïnvloeden.

\section{Hypothese 2}

In de tweede hypothese wordt verondersteld dat de werkdruk in een organisatie hoger wordt naarmate er meer sprake is van flexibilisering. Deze hypothese wordt ondersteund door de resultaten. De werkdruk stijgt naarmate meer sprake is van taak- en functieroulatie. Ook Goudswaard (2003) vindt een relatie tussen functionele flexibilisering (taak- en functieroulatie) en kwantitatieve werkdruk. Zij verklaart dit resultaat door te veronderstellen dat overschakelen van de ene 
taak naar de andere taak tijd kost. Ondanks het feit dat taak- en functieroulatie in de OSA-dataset gedefinieerd is als een situatie waarin werknemers elkaars taak overnemen zonder omsteltijd, kan de verklaring van Goudswaard ook voor de hier gevonden resultaten gelden. Taak- en functieroulatie worden in sommige bedrijven ook gebruikt om pieken in het werkaanbod op te vangen. Door deze vorm van taakroulatie mist een medewerker een rustmoment, dat hij wel zou hebben gehad zonder de taakroulatie, en dus werkt hij vaker onder tijdsdruk. Deze bevinding is van belang, omdat taak- en functieroulatie vaak ingezet worden als een maatregel om werkdruk te verlagen. De resultaten van dit onderzoek laten zien dat de wijze waarop taak- en functieroulatie worden ingezet het effect van deze maatregel sterk kan beïnvloeden.

Het percentage medewerkers dat te maken heeft met werken onder tijdsdruk stijgt naarmate het percentage medewerkers met een afroepcontract stijgt. Bij de verklaring van dit resultaat moeten we in gedachten houden dat de informatie verzameld is op organisatieniveau. Een bedrijf dat medewerkers met afroepcontracten in dienst heeft, heeft waarschijnlijk te maken met piekbelasting die door de reguliere medewerkers niet opgevangen kan worden. Hetzelfde zou kunnen gelden voor bedrijven met medewerkers met flexibele jaarcontracten. Deze medewerkers hebben een contract voor een vast aantal uren en de werkgever bepaalt wanneer meer of minder gewerkt wordt. Dergelijke contracten zullen ook vooral in bedrijven voorkomen die te maken hebben met pieken en dalen in belasting.

\section{Hypothese 3}

Reorganisaties zijn geen significante voorspellers van werkdruk, maar procesvernieuwing wel. Dit laatste resultaat was verwacht. Omdat zowel de vernieuwing als werkdruk op hetzelfde moment gemeten is, is niet vast te stellen of vernieuwing leidt tot werkdruk. Dat geldt voor alle hier beschreven relaties, maar bij deze relatie is het extra van belang, omdat verondersteld kan worden dat het effect van procesvernieuwing tijdelijk is. Echter, om te kunnen blijven beantwoorden aan een steeds veranderende vraag van de markt zullen bedrijven en instellingen hun productie- en dienstverleningsproces blijven vernieuwen. Verandering zal wellicht een 'permanente staat' van bedrijven worden, een werkdrukverhogende factor die altijd aanwezig zal zijn.

\section{Hypothese 4}

De belangrijkste verklarende factor is werkinhoud, en dan vooral fysiek zwaar werk en de gemiddelde inwerktijd. Smulders en Houtman (2004) vinden ook een relatie tussen fysiek zwaar werk en werkdruk. Zij verklaren dit door te veronderstellen dat fysiek zwaar werk een organisatie voor potentiële nieuwe werknemers onaantrekkelijk maakt en zo leidt tot onderbezetting. Onderbezetting leidt tot werkdruk voor de werknemers die wel in de sector werkzaam zijn. In de analyses beschreven in dit artikel is de variabele 'onderbezetting' meegenomen. Fysiek zwaar werk blijft een significante voorspeller van werkdruk, ook als gecontroleerd wordt voor onderbezetting. Ook voor een mogelijk effect van de interactie tussen fysiek zwaar werk en onderbezetting is geen bewijs gevonden. Een andere verklaring zou kunnen zijn dat ook fysiek werk tijd kost, misschien omschakeltijd van fysiek naar mentaal werk, maar zeker hersteltijd. Als deze hersteltijd niet genomen wordt, dan gaat dat op den duur ten koste van de snelheid waarmee het fysiek zware werk wordt uitgevoerd (iemand die moe is, zal langzamer werken). Dit kan uiteindelijk tot tijdsdruk leiden. Bovendien stelden Meijman, Furda en Kompier al in 1989 vast dat de motivatie van medewerkers daalt als de vermoeidheid stiigt.

De gemiddelde inwerktijd stijgt naarmate een functie ingewikkelder en complexer wordt. Ook de (mentale) zwaarte van de functie heeft een effect op werkdruk.

Vooral (mentaal) zwaardere functies hebben een langere inwerktijd. Dit zijn over het algemeen niet de functies waarin fysiek zwaar werk wordt verricht. De relatie tussen kenmerken van de functie en werkdruk zou wel eens een U-vormige relatie kunnen zijn.

\section{Vragen voor verder onderzoek}

De resultaten van dit onderzoek roepen ook een aantal nieuwe vragen op. 
Complexiteit en instabiliteit van de omgeving lijkt werkdruk in organisaties te verhogen, en interessant zou zijn om te onderzoeken hoe dat precies in zijn werk gaat. Klopt de veronderstelling dat omgevingskenmerken een effect hebben op de aard en hoeveelheid van de voorkomende regelproblemen? Op welk niveau uit zich dat precies, of is dat weer afhankelijk van de aard van de complexiteit van de omgeving?

Als het inderdaad zo is dat complexiteit en instabiliteit van de omgeving de aard en hoeveelheid van regelproblemen in een organisatie beïnvloeden, hoe kan een organisatie daarop dan het beste reageren? Is dat toch met autonome taakgroepen, zoals verondersteld wordt? Aan welke eisen moeten deze groepen dan voldoen?

Meer algemeen: beïnvloeden omgevingskenmerken de effectiviteit van maatregelen ter vermindering van werkdruk? Met andere woorden, zijn in bedrijven in een instabiele en complexe omgeving andere maatregelen effectief dan in bedrijven in een stabiele(re) en eenvoudig(ere) omgeving?

Ook flexibilisering lijkt werkdruk te verhogen. Dat geldt voor zowel functionele flexibilisering als voor contractflexibilisering. Omdat functionele flexibilisering juist ingezet wordt als maatregel tegen werkdruk, is het van belang te onderzoeken onder welke voorwaarden taak- en functieroulatie wel leiden tot een verlaging van werkdruk.

In dit onderzoek wordt een relatie gevonden tussen kwantitatieve flexibilisering en werkdruk. Als verklaring wordt hier gegeven dat gegevens op organisatieniveau verzameld zijn. Interessant zou het zijn om op het niveau van werknemers te onderzoeken of flexibilisering, zoals verondersteld, een negatief effect heeft op de mate waarin medewerkers van regelmogelijkheden gebruik kunnen maken. Als dat zo is, heeft flexibilisering vooral een negatief effect in bedrijven die opereren in een complexe en instabiele omgeving, gesteld dat deze kenmerken van de omgeving zorgen voor meer regelproblemen. Dat zou een belangrijk inzicht zijn, want juist deze bedrijven hebben een grote behoefte aan kwantitatieve flexibilisering. Procesvernieuwing lijkt werkdruk te verhogen. Dit zou een tijdelijk effect kunnen zijn. De veronderstelling is dat er tijd nodig is om te wennen aan de nieuwe werkwijze. Maar als vernieuwing en verandering een constante factor in organisaties gaan vormen, kost deze 'tijdelijke periode van gewenning' organisaties te veel tijd. Een interessante onderzoeksvraag zou zijn: kan een organisatie zo ingericht worden dat omgaan met veranderingen geen extra tijd meer kost?

\section{Implicaties voor de praktijk}

Wat hebben onze resultaten voor implicaties voor de praktijk, voor werkgevers en werknemers die proberen werkdruk in hun organisatie te verminderen?

In dit onderzoek is een aantal kenmerken gesignaleerd van organisaties en van de omgeving waarin organisaties opereren die een bijdrage leveren aan werkdruk in organisaties. Een aantal van deze kenmerken kan niet veranderd worden, of een verandering zou niet wenselijk zijn. Dat geldt vooral voor de omgevingskenmerken. Wel kunnen juist organisaties die voldoen aan deze kenmerken extra alert gemaakt worden op de risico's die medewerkers in hun organisatie lopen.

Andere kenmerken, zoals de mate van flexibilisering of de kenmerken van het werk kunnen wel aangepast worden. Bij de verschillende vormen van flexibilisering zouden randvoorwaarden in acht moeten worden genomen. In organisaties waar veel fysiek zwaar werk plaatsvindt, zouden maatregelen genomen kunnen worden om fysieke belasting te verminderen. Hiermee zou niet alleen de fysieke belasting maar ook de werkdruk verminderd worden. In ieder geval zullen rust- en hersteltijden in acht moeten worden genomen.

Sommige kenmerken komen in bepaalde sectoren meer voor dan in andere. In de sectoren Bouw en Zorg en Welzijn komt meer fysiek zwaar werk voor dan in andere sectoren. De sectoren Handel, Industrie, Bouw en Zakelijke Dienstverlening hebben meer te maken met complexe en instabiele omgevingsfactoren dan de andere sectoren. Flexibele jaarroosters komen vooral in de sectoren Handel, Zorg en Welzijn en Transport veel voor en in de Bouw is sprake van taak- en functieroulatie. Procesvernieuwing komt in het bijzonder in de sector Handel veel voor. Dit rechtvaardigt branche- of sectorspecifieke maatregelen en onderzoek. 
Vooral in organisaties die te maken hebben met concurrentie en een internationale markt werken medewerkers onder hoge tijdsdruk. In de toekomst zal dit voor steeds meer organisaties gaan gelden. Werkdruk zal daarom voorlopig nog op de agenda van overheid en werkgevers (moeten) blijven staan.

\section{Literatuur}

Ackroyd, S. \& S. Procter (1998). British Manufacturing Organization and Workplace Industrial Relations: Some attributes of the New Flexible Firm. British Journal of Industrial Relations, 36(2): 163-183.

Adler, P.S. \& B. Borys (1996). Two Types of Bureaucracy: Enabling and Coercive. Administrative Science Quarterly 41: 6189.

Bolwijn, P. \& T. Kumpe (1990). Manufacturing in the 1990's. Productivity, flexibility and innovation. Long Range Planning, 23(4): 44-57.

CBS (Centraal Bureau voor de Statistiek) (2001). Doorlopend Leefsituatie Onderzoek (DLO): Kerncijfers 2001-2002. Voorburg/Heerlen: CBS.

Cox, T., A. Griffith \& E. Rial-González, (2000). Research on work-related Stress. European Agency for Safety and Health at Work. Luxembourg: Office for Official Publications of the European Communities, http//www.eurofound.eu.int.

Elger, T. (1991). Taks Flexibility and the Intensification of Labour in UK manufacturing in the 1980s. In: Pollart (ed.). Farewell to Flexibility. Oxford : Basil Blackwell.

European Commission (1997). Green Paper, Partnership for a new organisation of work. COM (97) 128 Final, 16-4-1997, Luxembourg: Office for Official Publications of the European Communities, http//www.europe.eu.int.

Fouarge, D.J.A.G., M.J.M. Kerkhofs, A.M. de Voogd-Hamelink, J.P.M. Vosse \& C.J. de Wolff (2001). Trendrapport Vraag naar arbeid 2000. Den Haag: OSA.

French, J.R.P. \& R.D. Caplan (1970). Psychosocial factors in coronary heart disease. Industrial Medicine, 39: 383-397.
French, J.R.P., W. Rogers \& S. Cobb (1974). A Model of person-environment fit. In: G.W. Coehlo, D.A.Hamburg \& J.E. Adams (eds). Coping and Adaptation. New York: Basic Books.

Fröhlich, D. \& U. Pekruhl (1996). European Foundation for the Improvement of Living and Working Conditions (1996). Direct participation in organisational changeFashionable but misunderstood? An analysis of recent research in Europe, Japan and USA, Luxembourg: Office for Official Publications of the European Communities.

Goldenhar, L.M., L.J. Williams \& N.G. Swanson (2003). Modelling relationships between job stressors and injury and nearmiss outcomes for construction laborers. Work and Stress, 17(3): 218-240.

Goudswaard, A. (2003). Flexibele arbeid duurzame arbeid? De stand van zaken na twintig jaar flexibilisering van de arbeid. Hoofddorp: TNO Arbeid.

Jones, J.R., J.T. Hodgson, T.A. Clegg \& R.C. Elliot (1998). Self-reported work-related illness in 1995: results form a household survey. Sudbury: HSE Books.

Karasek, R. (1979). Job demands, Job decision latitude, and mental strain: implications for job redesign'. Administrative Science Quarterly, 24: 285-308.

Kompier, M.A.J., R.W.M. Gründeman, P. Vink \& P.G.W. Smulders (1996). Aan de slag. Tien voorbeelden van succesvolle reductie van ziekteverzuim. Alphen aan de Rijn: Samson.

Landsbergis, P.A., P. Schnall \& J. Cahill (1999). The impact of lean production and related new systems of work organisation on worker health. Journal of occupational Health Psychology, 4(2): 108-130.

Meijman, T., J. Furda \& M. Kompier (1989). Mentale belasting en werkstress: een arbeidspsychologische benadering. Assen: Van Gorcum.

Mintzberg, H. (1979). The structuring of organizations, Englewood Cliffs NJ: Prentice-Hall.

NCvB (2001; 2002). Signaleringsrapport beroepsziekten. Amsterdam: NCvB.

Oeij, P.R.A. \& N.M. Wiezer (2002). European Foundation for the Improvement of Living and Working Conditions. New work organ- 
De invloed van organisatiekenmerken op werkdruk in organisaties

isation, working conditions and quality of work: towards the flexible firm? Luxembourg: Office for Official Publications of the European Communities, http//www.eurofound.eu.int.

Otten, F. \& I.L.D. Houtman (2002). Werkdruk stabiliseert. Economisch-Statistische Berichten, 159.

Paoli, P. (2001). European Foundation for the Improvement of Living and Working Conditions. Third European Survey on Working Conditions - 2000. Luxembourg: Office for Official Publications of the European Communities.

Peeters, M.H.H. (1995). Groepswerk in sociotechnisch perspectief. Delft: Eburon.

Smulders, P.G.W. \& I.L.D. Houtman (2004). Oorzaken en effecten van werkdruk: een exploratief onderzoek. Tijdschrift voor Arbeidsvraagstukken, 20(1): 90-106.
Smulders, P.G.W., I.L.D. Houtman, \& D.J. Klein Hesselink (2001). Trends in arbeid 2002. Alphen aan den Rijn: Kluwer.

Vaas, F. (2004). Balanceren tussen uitdaging en stress. Een handleiding voor leidinggevenden en werknemers. Amsterdam: Thema Bedrijfswetenschappen.

Vaas, F., S. Dhondt, M.H.H. Peeters, J. Middendorp \& A. Vethman. (1995). De Weba Methode. Deel 1: Weba Analyse en Handleiding. Alphen aan den Rijn: Samsom Bedrijfsinformatie.

Wiezer, N.M. (1999). Sturing in organisaties. Een empirisch onderzoek naar de relatie tussen sturing en succes in 52 bedrijven. Amsterdam: Thela Thesis.

Wood S. (1988). Van Braverman naar Cyberman? Nieuwe technologie en arbeidsverhoudingen. Te elfder Ure 41. Het ontwerpen van arbeidsprocessen: 74-113. 